\title{
The Last Habitual Residence of the Deceased as the Principal Connecting Factor in the Context of the Succession Regulation (650/2012)
}

\author{
Max Atallah \\ Tallinn Law School, \\ Tallinn University of Technology \\ Akadeemia tee 3 , \\ Tallinn 12618, Estonia \\ E-mail: max.atallah@hotmail.com
}

\begin{abstract}
The objective of this study was to gather information about the last habitual residence (LHR) of the deceased in the context of the upcoming EU Succession Regulation. In addition, the aim was to analyze the adequacy of the legally undefined LHR as the principal connecting factor in cross-border succession within the EU. This study was carried out as a part of a bachelor thesis conducted on the same subject. The data were collected from relevant jurisprudence, international law, national acts, the EU published materials and case law. These results suggest that the legally undefined LHR is an unstable connecting factor for the purposes of the Succession Regulation, since it cannot guarantee sufficient legal certainty, and hence, the EU citizens are not able to fully utilize their right to free movement. The findings indicate that there might be a need to amend a legal definition for the LHR, not only for the EU Member States to be able to apply the concept in an harmonized way, but also for the EU citizens to know whether they are considered habitually resident in a state or not.
\end{abstract}

Keywords: connecting factor, last habitual residence (LHR), Succession Regulation (SR) 


\section{Introduction}

Approximately 11 million European Union (hereafter EU) citizens have exercised their right of free movement under the Founding Treaties (DG, 2010 , p. 5), and as a result there are about 450,000 cross-border successions in Europe a year, with an average value of 274,000 euros, making the total value of international successions in Europe a year over 124 billion euros (Commission of the European Union, 2009, Art. 18).

As a by-product of globalization, the cross-border succession within the EU is no longer a trivial matter. The monetary value of cross-border succession within the EU is substantial, and millions of EU citizens go through the process of cross-border succession. However, the EU has been unable to produce uniform rules to the cross-border successions within the EU, and consequently the Member States (hereafter MS) have been applying their own varying conflict of law rules on international successions. As a result, the EU citizens have not been able to utilize their rights to free movement. To tackle these problems the European Parliament and the Council presented a Regulation on 4 July 2012 on Jurisdiction, Applicable Law, Recognition and Enforcement of Decisions and Acceptance and Enforcement of Authentic Instruments in Matters of Succession and on the Creation of a European Certificate of Succession (hereafter SR), which entered fully into force on 17 August 2015.

The SR will not harmonize the substantive succession laws of the MS, but it unifies their conflict of law rules, with the exceptions of the UK, Ireland and Denmark, who did not take part in the SR and hence will not be bound by it (Harding, 2013, p. 208). A harmonization of the substantive succession laws of the MS is not possible because the EU does not have authority to intervene in the substantive family law of the MS, since the Treaty on the Functioning of the EU (hereafter TFEU) does not provide any legal basis for applying such a solution (Joamets \& Kerikmäe, 2013, p. 39). Therefore, the harmonization was limited to the MS's conflict of law rules (Council of the European Union, 2012, Preamble, Paras. 2 \& 4), by making the last habitual residence of the deceased (hereafter LHR) the main connecting factor in cross-border succession within the EU (Council of the European Union, 2012, Preamble, Para. 23). However, in Andrea Bonomi's opinion the conflict of law rules in the SR reflect a substantive policy even if they do not, per se, have an effect on substantive national succession laws (Ramaekers, 2011, p. 3). Furthermore, Kristi Joamets (2012, p. 97) talks about the disharmony of the family laws within the EU, and how the policy of the EU in that field is aimed at flexibility. 
The same principle can be applied to the SR where the Regulation cannot itself regulate the substantive laws of the MS, but still it manages to create a substantive policy for the MS.

The LHR of the deceased is the most important concept in the SR, because Articles 4 and 21 of the SR regulate the LHR to be the principal connecting factor in determining both the applicable law and the jurisdiction to the succession (Helin, 2013, p. 650). This paper will assess the suitability of the LHR as the principal connecting factor in the SR by analyzing the LHR and other connecting factors used in international succession in the context of the SR. After each connecting factor has been assessed, this paper intends to draw a conclusion on what would be the optimal connecting factor for the purposes of the SR. This paper approaches the subject of study from the hypothesis that the legally undefined last habitual residence is an unstable connecting factor in international successions, and therefore, the Succession Regulation is partly incompatible with the principle of legal certainty, and as a result the European Union citizens are not able to fully utilize their rights to free movement.

\section{Analyzing the connecting factors in the context of the Succession Regulation}

The connecting factors in private international law are used to determine the state with which a party is most closely connected (Siehr, 2005, p. 32). There are four connecting factors used to choose the applicable law and/or jurisdiction to a conflict of law situation, which are the LHR, lex domicilii, lex patriae and lex situs. As mentioned, the SR uses the LHR as the principal connecting factor for the purposes of choosing both the applicable law and jurisdiction to a cross-border succession, and it applies to the succession as a whole. The legislature chose the LHR because it was considered the most appropriate connection between movable and immovable estates, since the aim was to bring the entire estate under one single law. In addition, it raises less litigation than lex domicilii or lex patriae would. However, Angelique Devaux (2013, pp. 232-233) claims that there is a gap between this theory and practice, since the cross-border successions are such complex matters that it would require a more stable connecting factor than the legally undefined LHR. Since the whole choice of the LHR for the purposes of the SR has been questioned, this chapter 
will study each major connecting factor ${ }^{1}$ in order to better understand Devaux's claim and to create a basis for the assessment of the optimal connecting factor for the purposes of the SR.

\subsection{Last habitual residence}

The term 'LHR' is difficult to define exhaustively, and the Hague Conventions would seem to suggest that the term should not be defined in legal instruments at all, since the Conventions have been trying their hardest not to define the term (Bost, 2014, pp. 1153-1157; Siehr, 2005, p. 33). ${ }^{2}$ What is the reason for not defining the LHR in most international legal instruments? The legislators of international conventions have wanted to keep the concept of LHR flexible, and therefore, they have rejected including a legal definition of LHR in the Conventions. By keeping the term open, it grants the courts more freedom to decide whether or not a person has his LHR in a certain state, rather than being tied to strict rules, which could make the concept of 'LHR' too stiff and eventually inapplicable (Cavers, 1972, p. 485). How has the LHR been applied if it has not been provided a legal definition in the international conventions? The content of the LHR is derived from jurisprudence and case law of the European Court of Justice (hereafter ECJ) and the MS's courts, and therefore, there exist different interpretations of the concept.

As it can be seen, the SR follows the same ideology as its "siblings". However, even though the SR does not have a specific legal definition of the LHR, Paragraph 23 of the Preamble of the SR provides guidelines to the assessment of the LHR for the purposes of the SR: the assessment shall be based on an overall assessment of the circumstances of the deceased person by taking into account

1 'Major connecting factors' refer to the LHR, lex domicilii and lex patriae. This research paper will not assess lex situs in a separate chapter because, according to the $\mathrm{SR}$, the principle of scission shall not be applied. In certain jurisdictions the connecting factor in international successions is determined by the nature of the property: the law of the domicile, lex domicilii, is applied to movable property; and the law of the location, lex situs, applies to immovable property. This division is called the principle of scission.

2 Such Conventions are: Convention on the Conflicts of Laws Relating to the Form of Testamentary Dispositions (UN, 1961); Convention on the Establishment of a Scheme of Registration of Wills (UN, 1972); the Hague Convention Concerning the International Administration of the Estates of Deceased Persons (UN, 1973); Convention Providing a Uniform Law on the Form of an International Will (UNIDROIT, 1973); Convention on the Law Applicable to Trusts and on Their Recognition (UN, 1985); and Convention on the Law Applicable to Succession to the Estates of Deceased Persons (UN, 1989). 
all relevant factual elements. The emphasis of the assessment shall be on the "duration and regularity of the deceased's presence in the state concerned and in the conditions and reasons for that presence". Furthermore, the assessment shall be based on the years preceding the deceased's death and at the time of his death, and so there is no specific mention of the future intentions of the deceased. However, the Preamble continues that in difficult cases the determination of the LHR could be based on some form of intention from the deceased's part, even though there is still no clear mention of future intention anywhere in the SR. ${ }^{3}$ Therefore, it would seem that the determination of the LHR of the deceased shall not be based on the future intentions of the deceased person, but only on the assessment of facts and some form of intentions that can be derived from the years preceding his death and at the time of his death. However, it is worth mentioning that the afore-analyzed is only derived from the Preamble of the SR, and therefore, it is uncertain how the LHR will in actuality be applied in the future for the purposes of the SR.

Since the SR is not yet fully effective, there is no direct case law on the interpretation of the LHR in the context of the SR. Therefore, it is impossible to know for certain how the LHR will be interpreted. However, some guiding principles can be declared from the ECJ's earlier case law on different, but close, subject matters. In the case $A$, the ECJ set a precedent on what is to be considered the LHR of a child for the purposes of the Brussels II Regulation (A., 2009, Para. 20.2). The ECJ held that the emphasis of the assessment should be on the duration, regularity, conditions and reasons for the stay in a MS, and on the nationality, the place and conditions of attendance at school, linguistic knowledge and the family and social relationships (A., 2009, Para. 39). The Supreme Court of Finland has given a supporting ruling on a similar matter concerning the LHR of a child (Finnish Supreme Court, 2008, Para. 13). ${ }^{4}$ However, it is important to keep in mind that the LHR of a child differs greatly from that of an adult since the life of an adult is significantly more complex, and

3 Paragraph 24 of the Preamble of the SR provides examples of where such difficult cases may arise. For example, if the deceased person had moved abroad for economic or professional reasons. In such a situation, the overall assessment could lead to the determination that the LHR of the deceased is the state of origin where the deceased's family and social life was located. Another example is if the deceased lived in various states, not having settled anywhere. In such a case, the nationality of the deceased or the location of his assets could be used in determining his LHR.

4 The court held that the LHR of a three- and a one-year-old child who had lived their whole lives in Finland were not transferred to Scotland after six months of living in Scotland. The court viewed that the children could not have developed stronger social ties to their family in Scotland than what they had formed to their family in Finland. 
therefore, the aforementioned interpretations cannot be used exhaustively when interpreting the LHR in the context of the SR. These uncertainties have a risk of resulting in difficulties predicting what body or court will handle a given case, and the uncertainties form impediments to the rights of free movement since the EU citizens might not want to utilize their rights due to the uncertainty.

Many legal scholars suggest that the term 'LHR' ought to be legally defined in the SR, since the concept shall be applied in various different jurisdictions. Professor David Hayton (2004, p. 365) claims that it would be necessary to set a common definition of a person's sole habitual residence for the purposes of the law of succession, because all jurisdictions ought to apply the LHR in a same way, in order to have a workable and satisfactory instrument that would diminish the threat of forum shopping. Hayton (2004, p. 363) further contends that the lack of legal definition makes the LHR "indefinitely arbitrary", and Angelique Devaux (2013, pp. 232-233) claims that, as a result, it might incur professional civil liability and tensions between the heirs, as the lawyers that, most likely, have never met the deceased are put in the position of "detectives" who shall determine the LHR of the deceased. Professors Carruthers and Crawford, who represent the UK perspective, argue that the LHR should at least be legally defined in the SR, since the lack of definition has potential to cause significant uncertainty, which will surely result in a significant number of inappropriate outcomes. Furthermore, Carruthers and Crawford contend that the LHR has potential to be a very fragile connecting factor since the concept has proved notoriously productive of disputation and litigation, as the case law would suggest that a person could have more than one habitual residence, or no habitual residence at all (Crawford \& Carruthers, 2010, pp. 65-66).

\subsection{Lex domicilii}

Lex domicilii uses the law of the domicile as the deciding factor in a conflict of law situation. Domicile has several different national definitions, and therefore, the international popularity of lex domicilii has lessened since it cannot be used in international conventions (as such) in a harmonized way, nor can it be used to unify legislation between different states (as such) (Helin, 2013, p. 53). In order to clarify the situation, the paper will assess common law and civil law interpretations of domicile, ${ }^{5}$ after which the aim is to draw a conclusion on lex domicilii as a connecting factor for the purposes of the SR.

5 It is worth highlighting that the differences between the civil and common law systems are not restricted just to those systems, and so the interpretation of domicile varies between the civil law states and common law states as well. 
In the UK, 'domicile' is defined as a 'permanent home', and consequently a person cannot be without domicile and there can be only one domicile at a time (UK Visas and Immigration, 2011, SET15.1). The UK has divided the concept of domicile, in this context, into domicile of origin and domicile of choice. Domicile of origin is acquired at birth and so domicile of origin is usually formed by nationality (UK Visas and Immigration, 2011, SET15.2), which means that it has visible similarities with lex patriae. Domicile of choice occurs when the party concerned changes his domicile, for example, by moving to another state. In order for a domicile to change, the court requires evidence of the new residence and of a strong intention to live there indefinitely. The length of residence is not, by itself, conclusive, and so the assessment shall be based on the intention of the party concerned (UK Visas and Immigration, 2011, SET15.5). Intention is understood as the person's actual state of mind (Manko, 2013, p. 1), as any declaration of intent to remain permanently, or to retire in a place, are considered important, but should be viewed in the context of a person's actions to see whether the two are consistent (UK Visas and Immigration, 2011, SET15.6).

In addition, certain civil law states use the concept of lex domicilii as a connecting factor in international successions, but the definition of domicile differs from its common law counterpart. In Finland, there is no legal definition of domicile in any legal act, and so the content of the concept is derived from the case law and jurisprudence. According to the Finnish government proposals, for a residence in a state to constitute a domicile, the nature of the residence in the state concerned has to resemble permanent residency. The change of domicile can occur only if the party concerned has settled to live in a new state, and he has an intention to stay and live there permanently. Therefore, if one would move to a new state to study or work for a limited period of time, it would not result in a domicile (Helin, 2013, p. 54; Government of Finland, 2001).

It can now be seen that there are some differences between the civil and common law interpretations of domicile, such as, the common law systems' distinction between domicile of origin and choice. However, there seems to be a unifying term between the interpretations, which is the 'intention' of the party concerned. Compared to the LHR, lex domicilii seems to put more emphasis on the intention of the deceased, which would seem to make lex domicilii a more concrete connecting factor if the intent of the deceased could be shown easily. However, since in most cases the intent of the deceased would be difficult to determine, and the term 'domicile' is understood differently in different states, and the common law interpretation might be difficult to apply in civil law states, and vice versa, it is understandable that the EU did not want to make lex domicilii the principal connecting factor for the purposes of the SR. 


\subsection{Lex patriae}

Nationality as a connecting factor was a by-product of nationalism, the goal of which was to promote the sovereignty of the states. The law of the state which nationality is in question determines the nationality. Hence, the Finnish law only determines who are considered Finnish nationals, and the Estonian law determines who are Estonian nationals, and so on. The nationality of a person is usually found by looking at the official documents a person usually carries with him (Helin, 2013, p. 57). Therefore, the advantage of lex patriae is considered to be its easy applicability compared to the LHR and lex domicilii, which both require a lot of discretionary interpretation. There is usually no such discretion needed when applying lex patriae. However, the applicability of lex patriae is not always such an easy task, if for example, a state ceases to be, or there exist difficulties in proving the nationality of the party concerned. In addition, the rise of dual citizenships due to globalization presents its own difficulties, as there develops a need to regulate supplementary provisions for such cases (Helin, 2013, pp. 57-58).

Lex patriae is a formal connecting factor, and it does not entail interpretation of circumstances. Therefore, the deceased might not always have a real connection to the state the nationality of which he possesses. Is it justifiable to let such a state handle the succession of the deceased? In addition, lex patriae is inappropriate for the integration policy of the EU, which aims to ease the integration of the EU citizens in the MS of their habitual residence. This is the main reason why the Commission does not favour lex patriae in its proposals, even though it recognizes that lex patriae has to be accepted in some form, as the MS's traditions require so. Moreover, since the EU's legal principle of non-discrimination set forth in Article 18 of the Treaty of the European Union (hereafter TEU) applies to the private international law matters, it complicates the use of lex patriae as a connecting factor (Helin, 2013, p. 58). Furthermore, the concept of EU citizenship works against lex patriae, since the EU citizenship promotes the unity of the EU citizens, whereas lex patriae distinguishes beteween the nationalities of the EU citizens. 


\section{What would be the optimal connecting factor in cross-border succession within the EU?}

It would seem that there are only bad choices available since the harmonization of the substantive succession laws of the MS is not possible. ${ }^{6}$ Therefore, the EU seems to be fighting a battle it cannot win. As long as the EU is not given tools to harmonize the substantive family laws of the MS, it cannot produce a solution that would bring sufficient clarity and mobility required by the crossborder successions. However, for the purposes of this research, this paper will next assess the optimal connecting factor for the purposes of the SR.

Values play an important role in the process of lawmaking, and hence, the values of the EU have to be taken into consideration when suggesting the optimal connecting factor for the purposes of the SR. The objective of the legislature is to recognize what is considered important by the population, so that the laws reflect the values of the society (Joamets, 2012, p. 109). According to Article 2 of the TEU, the EU is a community based on the rule of law, which means that every action taken by the EU is founded on Treaties, approved voluntarily and democratically by all the EU MS (EU, 2014). Furthermore, the rule of law includes the principle of legal certainty (Commission of the European Union, 2014, p. 1), which is derived from the case law of the ECJ (Amministrazione delle finanze dello Stato $v$ Salumi, 1981, Para. 10). Consequently, since the Union is founded on the values of respect for the rule of law (Joamets, 2014b, p. 22), it can be declared that the free movement of persons is such a value, because it is one of the four freedoms supporting the foundation of the European Community, as well as a principle derived from the Founding Treaties, Article 3, Paragraph 2 of the TEU and Articles 21, Paragraph 2 and Article 45 of the TFEU (Joamets, 2014b, p. 6). Moreover, the free movement of persons is included into Article 45 of the EU Charter of Fundamental Rights and strengthened by the emergence of the EU citizenship (Joamets, 2014a, p. 142), which aims to unify the citizens of the MS (EU, n.d.). In addition, the principle of non-discrimination brings its own obstacles, as the EU citizens, whatever their nationality, ought to be equal. Therefore, the connecting factor in the context of the SR has to promote the right to free movement, right to non-discrimination, and the principle of legal certainty.

Since the nationality of the deceased is usually easy to determine, and there are no severe discrepancies in the application of lex patriae between the MS, lex

6 See 'Introduction' of this paper, which explains why the EU cannot intervene in the substantive succession laws of the MS. 
patriae would seem to be the most concrete connecting factor for the purposes of the SR out of the choices available. Therefore, lex patriae would primarily promote the principle of legal certainty and for these reasons, Angelique Devaux (2013, p. 233) supports lex patriae as a principal connecting factor for the purposes of the SR. However, since lex patriae endorses the sovereignty of the states and not the unity of the EU citizens, the choice could be interpreted as being contrary to the EU's integration policy, and therefore, it can be seen as hindering the right to free movement. Furthermore, lex patriae is not without its own uncertainties, and therefore, the choice would not bring a sudden end to the uncertainties of interpretations.

Contrary to lex patriae, the LHR would seem to promote the free movement of persons and the integration policy of the EU, since it will not "lock" the deceased into a specific legal system. Rather, it provides a mobile concept for the deceased, where he can fully take advantage of the right to free movement. Furthermore, the LHR promotes the principle of non-discrimination, as there is principally no division between the MS's citizens and the EU citizens, since the LHR applies to the succession as a whole. However, such equality will bring rise to the unwanted forum shopping, and in addition, the uncertainties involved in the application of the legally undefined LHR create difficulties with the principle of legal certainty. Therefore, despite having justified reasons for not defining the term 'LHR', the application of the LHR between 28 different MS could be seen as requiring a concrete definition of the term, since it is impossible to apply the undefined LHR in a harmonized way between nearly $30 \mathrm{MS}^{7}$ Therefore it can be claimed that a common legal definition of the LHR for all the MS would outweigh the more flexible, but uncertain, undefined LHR.

Lex domicilii seems to combine the aforementioned concepts, and the result is something in between. Lex domicilii is similar to the LHR, but the concept of domicile seems to give more emphasis to the actual 'home state' of the deceased, which could be seen as providing the means for the MS to avoid forum shopping. Moreover, since the domicile can change, lex domicilii could be seen as promoting the free movement of persons and the integration policy of the EU. As for the case of intent, it would seem to work both ways. On the one hand, taking the intent of the deceased into consideration would seem only reasonable, but on the other hand, how can the intent be shown in actuality if the deceased did not declare it anywhere. Would this create a

7 Also, Michaela Navrátilová considers the undefined LHR a disadvantage to the SR (Ramaekers, 2011, p. 3). 
loophole for arbitrary reconciliation of domicile and intent? The intent of the deceased could be seen as mirroring lex patriae, since it would usually refer the succession to the state of the deceased's nationality. However, the biggest point to be made here is the fact that there is no unified concept of domicile within the EU, and for this reason lex domicilii would have to be legally defined if it was chosen as the principal connecting factor for the purposes of the SR. However, it would not be such an easy task to draft a legal definition of domicile that would be agreeable in all the MS since the understanding of the concept is not sufficiently unified.

So what would be the best connecting factor? Based on this research, the LHR would seem to be the optimal connecting factor for the purposes of the SR. However, the term 'LHR' ought to be legally defined in the SR, because without a concrete definition of the concept, the MS are not able to interpret the LHR in a unified way. The jurisprudence and the case law would seem to support this claim. Out of the three choices available, the LHR would seem to balance the values of the EU in the best way, and if the term was legally defined, the difficulties in the interpretation of the LHR would be reduced. Therefore, the optimal connecting factor for the purposes of the SR would be the legally defined LHR.

Lastly, this paper analyzes what could be the legal definition of the LHR for the purposes of the SR. David Hayton's view will be compared to the Belgian and the Swiss legal definitions of the LHR, after which this paper proposes a legal definition of the LHR. Hayton's suggestion was chosen as the subject of study since the definition suggested in his article provides a comprehensive outline of the LHR, and leaves room for further construction. It is necessary to study the available national legal definitions of the LHR in order to provide a sufficient suggestion for a common legal definition of the LHR for all the MS. Because there are not many legal definitions of the LHR available in national legislations, the study was constructed of the legal definitions of the LHR that were available in Europe, since the SR is an EU instrument. Hence, the Belgian and Swiss PIL's legal definitions of the LHR were chosen as the subjects of study.

As mentioned earlier, the case law and the jurisprudence would suggest that a person could have more than one habitual residence or no habitual residence at all. Therefore, Hayton (2004, p. 365) claims that the possible definition of the LHR should "make it clear that every person must have a LHR before death even if a person at the time of his death is only a resident — and not habitually resident - in the jurisdiction where he died". Hayton (2004, p. 365) further 
continues that the core of the definition could be "the last voluntarily acquired main centre of a person's personal, ${ }^{9}$ social and economic life". Hayton's suggestion would seem to create such a concrete basis for the definition of the LHR that it partly resembles lex domicilii.

Article 4.2 of the Belgian Code on Private International Law defines the LHR as

the place where a natural person has established his main residence, even in the absence of registration and independent of a residence or establishment permit; in order to determine this place, the circumstances of personal or [professional] nature that show durable connections with that place or indicate the will to create such connections are taken into account (Maisto, 2010, p. 35).

Alternatively, Article 20(1)(b) of the Swiss Federal Code on Private International Law defines the LHR as "the state in which he lives for an extended period of time, even if this time period is limited from the outset." (Maisto, 2010, p. 35) This has raised questions on how long the residence ought to be. The Belgian and the Swiss definitions are not directly targeted to cover only international successions, and therefore, the definition provided by Professor Hayton might be better suited for the purposes of drafting a legal definition for the LHR in the context of the SR. However, the Swiss and Belgian definitions of the LHR would also seem to draw distinctions from lex domicilii, as the definitions consist of such concrete criteria that they basically require a domicile for the LHR to constitute 'the LHR'.

The definitions share several similarities: mobility of the concept; intent of the person concerned; the use of 'personal life' instead of 'family life'; the person concerned has to have lived in the state concerned; and the necessity of some form of durability of stay. ${ }^{10}$ Hence, all the aforementioned criteria ought to be fitted into the suggestion. It is worth mentioning that the durability of stay should not be set within a strict time limit since it might severely hinder the EU's aims to have the MS apply their own laws in most of the cross-border successions, which can be derived from Articles 4 and 21.1 of the SR (Helin, 2013, p. 679). Therefore, the undoubtedly concrete concept of permanent residence in the

8 For example, a person could be a prisoner, hostage or a patient in a foreign state. In addition, by regulating 'voluntarily acquired', minors are provided with sufficient protection.

9 'Personal life' is more versatile than 'family life', since not all persons have family.

10 Even though Hayton does not specifically mention durability, it can be derived from the suggested definition, since a person cannot acquire a "centre of personal, social and economic life" without durable stay in the state concerned. 
Member State concerned should not be included in the definition (EU, 2015), nor should the criteria of an 'extended period of time' from the Swiss legal definition. Furthermore, it can be derived from Paragraph 23 of the Preamble of the SR that the meaning of the LHR is intended to be defined more by reference to a person's centre of vital interests rather than the duration of a person's stay in a certain state (Bohan \& McCarthy, 2013, p. 79).

Even though the definition of the LHR ought to provide some form of mobility, it must also serve the principle of legal certainty. Because the EU left the term LHR legally undefined, they weighed in favour of mobility at the expense of legal certainty, and as argued in this article, this creates severe problems in the application of the SR. Hence, the suggestion ought to weigh more in favour of the principle of legal certainty while trying not to forget the mobility of the LHR. Moreover, since the descriptive text of the LHR in the Preamble of the SR is formed so extensive, the legal definition of the LHR should not be limited into too constrictive form, even if the aim is to promote legal certainty. Furthermore, since there are clear indications that the LHR is understood in a different way between MS, and since the SR does not provide any legal definition of the LHR, a common legal definition of the LHR for all the MS to apply will most likely ease the uncertainties, even if the legal definition itself is kept somewhat mobile. The suggestion is structured by combining Professor Hayton's suggestion with the Belgian PIL's definition of the LHR. Therefore, the legal definition of the LHR could be the last voluntarily acquired main centre of a natural person's personal, social and economic life; in order to determine this place the nature of stay must show durable connections with that place or indicate an intention to create such connections.

\section{Conclusion}

When the SR was being drafted, there was a need to choose a unifying connecting factor for all the MS in cross-border succession situations, because the EU does not have jurisdiction to regulate the substantive laws of the MS in this matter. Since the principle of scission would not be applied to the SR, there were three main connecting factors to choose from: the LHR, lex domicilii, and lex patriae. The LHR was chosen as the principal connecting factor for crossborder succession within the EU because the legislator felt that it had the most appropriate connection between movable and immovable estates, since the aim was to bring the entire estate under one single law. In addition, since the concept 
of the LHR is applied in a more harmonized way than lex domicilii, and since the LHR is not as stiff as lex patriae, it results in less litigation than lex domicilii or lex patriae would. The LHR would seem to be the best connecting factor to serve the purposes and goals of the EU in cross-border successions within the EU, but since the LHR has not been legally defined in the SR, the EU's choice to keep the LHR mobile and flexible at the expense of legal certainty will most likely result in more harm than good.

The legally undefined last habitual residence is an unstable connecting factor in international successions, and therefore, the Succession Regulation is partly incompatible with the principle of legal certainty, and as a result the European Union citizens are not able to fully utilize their rights to free movement. Is it even theoretically possible that 28 different MS would be able to apply a legally undefined concept in a harmonized way? It is clear from the jurisprudence and the case law that the undefined LHR has not been applied in a unified way, and therefore, it is unlikely to happen in the case of the SR. Furthermore, since the subject matter is so strongly and differently litigated in each Member State, there is a dire need for an unambiguous definition of the LHR, in order for the EU citizens to know whether they are considered habitually resident in a Member State or not. The ECJ will surely shine light on the legal meaning of the LHR once the first court cases on the subject are being dealt with, but until then, the LHR is an unstable connecting factor, even if it is a mobile and flexible one. To conclude, the SR brings a much-needed easement for crossborder successions within the EU, but the choice of leaving the term 'LHR' legally undefined, makes the SR partly incompatible with the principle of legal certainty and, ultimately, with the principle of free movement.

Max Atallah is a bachelor's degree graduate in European Union law and international law from Tallinn Law School of Tallinn University of Technology. His research focuses on the upcoming European Union Succession Regulation (650/2012) which will harmonize the conflict of law rules in cross-border succession within the European Union. He is also a legal research assistant at Tallinn Law School. 


\section{References}

A. (2009), Opinion of Advocate General Kokott delivered on 29 January 2009, ECR I-02805, C-523/07.

Amministrazione delle finanze dello Stato v Salumi [1981], ECR 2735, C-261/96.

Bohan, B. \& McCarthy, F. (2013), Capital Acquisitions Tax, $4^{\text {th }}$ edition, Dublin: Bloomsbury Professional.

Bost, J. (2014), 'Nothing certain about death and taxes (and inheritance): European Union regulation of cross-border successions,' Emory International Law Review, vol. 27 , no. 2, pp. 1145-1174.

Cavers, D. (1972), “'Habitual residence': a useful concept?” American University Law Review, vol. 21, no. 3, pp. 475-493.

Commission of the European Union (2005), Green Paper on Succession and Wills, COM (2005) 65 final, 1.3.2005.

(2009), Commission Staff Working Document, Accompanying the Proposal for a Regulation of the European Parliament and of the Council on Jurisdiction, Applicable Law, Recognition and Enforcement of Decisions and Authentic Instruments in Matters of Successions and on the Introduction of a European Certificate of Inheritance, Impact Assessment, SEC (2009) 410 final, 14.10.2009. (2014), Annexes 1 and 2 to the Communication from the Commission to the European Parliament and the Council on a new EU framework to strengthen the Rule of Law, COM (2014) 158 final, 11.3.2014.

Council of the European Union (2003), Council Regulation 2201/2003/EC concerning jurisdiction and the recognition and enforcement of judgments in matrimonial matters and the matters of parental responsibility, repealing Regulation (EC) No. 1347/2000, Official Journal of the European Union, L 338, 27.11.2003.

(2012), Council Regulation 650/2012/EU of the European Parliament on jurisdiction, applicable law, recognition and enforcement of decisions and acceptance and enforcement of authentic instruments in matters of succession and on the creation of a European Certificate of Succession, Official Journal of the European Union, L 201/107, 4.7.2012.

Crawford, E. \& Carruthers, J. (2010), 'Written evidence-Letter from Professor Elizabeth Crawford, Professor of International Private Law, and Dr. Janeen Carruthers, Reader in Conflict of Laws, University of Glasgow,' in The EU's Regulation on Succession: House of Lords, European Union Committee, $6^{\text {th }}$ Report of Session 2009-10, London: TSO, pp. 62-66.

Devaux, A. (2013), 'The European regulations on succession of July 2012: a path towards the end of the succession conflicts of law in Europe, or not?' The International Lawyer, vol. 47, no. 2, pp. 229-248. http://dx.doi.org/10.2139/ssrn.2230663 
DG (2010), Freedom to Move and Live in Europe: A Guide to Your Rights as an EU Citizen, Directorate-General for Justice, European Commission.

EU (n.d.), Citizenship of the European Union. Retrieved from http://europa.eu/ legislation_summaries/institutional_affairs/treaties/amsterdam_treaty/a12000_ en.htm [accessed 12 May 2015]

- (2008), Consolidated Version of the Treaty on the Functioning of the European Union, Official Journal of the European Union, C 115/47.

— (2010), Consolidated Version of the Treaty on European Union, Official Journal of the European Union, C 83/01.

(2012), Charter of Fundamental Rights of the European Union, 2012/C 326/02, 26.10. 2012.

— (2014), Rule of Law, September 2014. Retrieved from http://ec.europa.eu/ enlargement/policy/policy-highlights/rule-of-law/index_en.htm [accessed 12 May 2015]

— (2015), Permanent Residence (>5 years) for EU Nationals, February 2015. Retrieved from http://europa.eu/youreurope/citizens/residence/documentsformalities/eu-nationals-permanent-residence/index_en.htm [accessed 12 May 2015]

Government of Belgium (2004), Belgian Code on Private International Law, 16 July 2004.

Government of Finland (2001), Hallituksen esitys Eduskunnalle eräiden avioliittoa ja perimystä koskevien kansainvälisen yksityisoikeuden alaan kuuluvien säännösten undistamisesta, HE 44/2001, LaVM 20/2001.

Government of Switzerland (1987), Swiss Federal Code on Private International Law, 18 December 1987.

Harding, M. (2013), Conflict of Laws, $5^{\text {th }}$ edition, Abingdon \& New York: Routledge.

Hayton, D. (2004), "Determination of the objectively applicable law governing succession to deceaseds' estates," DNotl, Les Succesions Internationales dans I'UE, pp. 359-370.

Helin, M. (2013), Suomen kansainvälinen perhe ja perintöoikeus, Helsinki: Talentum.

Joamets, K. (2012), 'Marriage capacity, social values and law-making process,' ICLR, vol. 12 , no. 1 , pp. 97-115.

(2014a), 'Civil status registration-more than data collection: EU digital development in promoting the free movement of civil status document,' in $\mathrm{T}$. Kerikmäe (ed.) Regulating eTechnologies in the European Union: Normative Realities and Trends, Cham, Heidelberg etc.: Springer International Publishing Switzerland, pp. 141-156.

- (2014b), Gender as an Element of Marriage Capacity in the Context of National and Supranational Law in the European Union, Ph.D. thesis, Tallinn University of Technology. 
Joamets, K. \& Kerikmäe, T. (2013), 'The new developments in the EU family law-its applicability to Estonian law,' Korea University Law Review, vol. 13, pp. 25-42.

Maisto, G. (2010), Residence of Individuals under Tax Treaties and EC Law, vol. 6, Amsterdam: IBFD Publications BV.

Manko, R. (2013), “'Habitual residence' as a connecting factor in EU civil justice measures," Library Briefing of the Library of the European Parliament 22/01/2013, no. 2013-427. Retrieved from http://www.europarl.europa.eu/ RegData/bibliotheque/briefing/2013/130427/LDM_BRI\%282013\%29130427_ REV1_EN.pdf [accessed 12 May 2015]

Ramaekers, E. (2011), 'Cross-border Successions. The New Commission Proposal: Contents and Way Forward. A Report on the 2010 Academy of European Law Conference of 18 and 19 February 2010, Trier,' Electronic Journal of Comparative Law, vol. 15.1, pp. 1-6.

Siehr, K. (2005), 'General problems of private international law in modern codifications: De Lege Lata and De Lege Europea Ferenda,' in P. Šarčević, P. Volken \& A. Bonomi (eds.) Yearbook of Private International Law, Munich: Sellier European Law Publishers \& The Swiss Institute of Comparative Law, vol. 7, pp. 17-61.

Supreme Court of Finland (2008), Decision of the Finnish Supreme Court, KKO:2008:98, 17.11.2008.

UK Visas and Immigration (2011), 'Domicile: SET15,' UK Visas and Immigration settlement application guidance on domicile, 25 August 2011.

UN (1961), Convention on the Conflicts of Laws Relating to the Form of Testamentary Dispositions, 510 U.N.T.S. 175, 5 October 1961.

(1972), Convention on the Establishment of a Scheme of Registration of Wills, E.T.S. No. 77, 1138 U.N.T.S. 243, 16 May 1972.

- (1973), Convention Concerning the International Administration of the Estates of Deceased Persons, 1856 U.N.T.S. 5, 2 October 1973.

- (1985), Convention on the Law Applicable to Trusts and on Their Recognition, 1664 U.N.T.S. 311, 1 July 1985.

- (1989), Convention on the Law Applicable to Succession to the Estates of Deceased Persons, 28 I.L.M 150, 1 August 1989.

UNIDROIT (1973), Convention Providing a Uniform Law on the Form of an International Will, International Institute for the Unification of Private Law, Washington, D.C., 26 October 1973. 